\title{
THE EFFECT OF ANTIBIOTICS AND ACIDIFIER TREATMENT ON THE COUNT OF LACTOBACILLUS SP., E. COLI AND CLOSTRIDIUM SP. IN THE INTESTINE OF CHICKENS
}

\author{
Ellakany, H.F. ${ }^{1}$; Rayhan, E.A. ${ }^{2}$; Awad, A.M. ${ }^{1}$; Abd El-Hamid, H.S. ${ }^{3}$ \\ ${ }^{1}$ Poultry and Fish Diseases Dept., Fac. Vet. Med., Alexandria University \\ ${ }^{2}$ Animal Health Research Institute, Damanhour Branch \\ ${ }^{3}$ Fac. Vet. Med., Alexandria University, Damanhour Branch
}

\begin{abstract}
The effect of addition of some commonly used antibiotics and acidifier on the total bacterial count of defined intestinal microflora as Lactobacillus sp., E. coli, and Clostridium sp. with special reference to $\mathrm{Cl}$. perfringens was studied.

Two antibiotic doses were used: from 14-16 ${ }^{\text {th }}$ day of age and again from $29^{\text {th }}-31^{\text {st }}$ day of age. The second course was followed by an acidifier for 3 days.

Results showed that doxycycline and amoxicillin had the most inhibitory effects on Lactobacillus sp. This inhibitory effect was more pronounced if an acidifier was used after these antibiotics than if they were used alone.

Cephradin, spiramycin, doxycycline, tylosin, floramphenicol and enrofloxacin showed good inhibitory effects on E. coli. This result concerning E. coli can not be taken as a model of recommendation because the continuous change in the drug resistance of this bacterium.

Spiramycin, cephradin, amoxicillin, doxycycline, tylosin, lincospectin and enrofloxacin were effective against $\mathrm{Cl}$. perfringens and other Clostridium sp. The antibacterial action of these antibiotics was increased if an acidifier was used afterwards.

One week after the end of the antibiotics and acidifier treatment, there was a decrease in both Lactobacillus sp., E. coli and Clostridium sp. counts in the intestine with one log lower $\left(10^{4}\right)$ than that count in case of antibiotics without acidifier $\left(10^{5}\right)$. This finding encourages us to recommend usage of acidifiers for chicken specially after antibiotic courses to prolong their antibacterial activity.
\end{abstract}




\section{INTRODUCTION}

The gastrointestinal (GI) tract of animals contains as many as 500 bacterial species of microflora, up to $10^{12}$ bacterial cells/g of feces (Savage, 1977; Mackie et al., 1999; Moore and Holdeman, 1974; Savage, 1977; Lee, 1984; Jensen, 2001). These numbers are consistent with the estimation that bacterial cells outnumber host cells by 10:1 (Gaskins, 2001).

Aerobic and facultative anaerobes including Escherichia coli, lactobacilli, and streptococci which all colonize immediately after birth (Smith and Jones, 1963; Mackie et al., 1999). Numbers are low; between $10^{2}$ and $10^{5} \mathrm{cfu} / \mathrm{mL}$ of digesta, but these numbers rapidly increase. These species provide a reduced environment, which in turn allows for establish-hment of the obligate anaerobes (Bacteroides, Bifidobacterium, and Clostridium) that appear later, and constitute the predominant species of the stable microflora.

The gut associated microflora exert a bad influence on animal health and performance through different mechanisms. They compete for nutrients with the host (Furuse and Okumura, 1994). Experiments have demonstrated that as much as $6 \%$ of the net energy in the pig diet is lost to the microflora (Vervaeke et al., 1979). Bacteria also compete with the host for uptake of amino acids, thereby reducing nitrogen utilization (Furuse and Yokota, 1985).

The gut associated microflora produce toxic mino acid catabolites, decrease fat digestibility, and necessitates great increases in mucus secretion and gut epithelial cell turnover. This high cell turnover is accompanied by an extremely high rate of metabolism and protein synthesis, resulting in 23 to $36 \%$ of the whole body energy expenditure (Summers, 1991; Cant et al., 1996). 
Thus antibiotic growth promoters (AGP) decrease competition for nutrients produced by the gut flora, reduce the microbial amonia, amines, and phenols from amino acid fermentation that depress growth and prevent the bile catabolism (Visek, 1978a; Anderson et al., 1999, Feighner and Dashkevicz, 1987, 1988; Gaskins et al., 2002).

It's been reported that gut bacteria and changes in the microbial community could affect the chicken immune system. Virginiamycin treatment altered the variety of bacteria, including beneficial bacteria within the Lactobacillus family (Lactobacilli are commonly used as probiotics in poultry production).

The bacterial population influences a variety of immunological, physiological, nutritional, and protective processes of the GI tract and exerts profound effects on the development performance of monogastric animals. Commensal bacteria play important roles in organ, tissue, and immune system development, as well as providing a variety of nutritional compounds (Gaskins, 2001; Snel et al., 2002).

The antibiotics are widely used in the practice of poultry production. Hence the different classes of antibiotics differ in their mode of action on pathogenic bacteria, it is expected that they have different side effects on the gut flora.

\section{The aims of this study were to know:}

1- What are the effects of certain antibiotics on E. coli, Clostridia sp. (with special reference to $\mathrm{Cl}$. perfringens) and Lactobacillus sp. counts in the growing chicken gut?

2- If the acid treatment after an antibiotics treatment would help espeiclly in rapid repopulation of useful Lactobacillus bacteria and further inhibit the repopulation of other pathogenic species? 


\section{MATERIAL AND METHODS}

\section{Experimental design:}

100 male Bouvans layer chicks were divided randomly into 10 groups, each containing 10 chicks. Each group received 2 antibiotic treatment courses each for 3 successive days from $14^{\text {th }}-16^{\text {th }}$ day of age and again the $29^{\text {th }}-31^{\text {st }}$ day of age. After the end of the second course at $29^{\text {th }}-31^{\text {st }}$ day of age, treatment was followed by acidifier for 3 days in the drinking water.

From each group, 3 birds were killed and examined microbiologically (for the intestinal counts of Lactobacillus sp., E. coli, Clostridium sp. with special reference to $\mathrm{Cl}$. perfringens) for 3 successive days and once again after 7 days after the end of each treatment course.

Table (1): Experimental design.

\begin{tabular}{|c|c|c|}
\hline group & Treatment & Dose \\
\hline 1 & Cephradin $20 \%$ & $10 \mathrm{mg} / \mathrm{kg}$ body weight equivalent to $0.5 \mathrm{~g} / 1$ liter DW \\
\hline 2 & Spiramycin & $70,000 \mathrm{iu} / \mathrm{kg}$ body weight equivalent to $0.5 \mathrm{~g} / \mathrm{liter} \mathrm{DW}$ \\
\hline 3 & Nitroimidazole & $1 \mathrm{ml} / 1$ liter DW \\
\hline 4 & Doxycyclin $50 \%$ & $20 \mathrm{mg}$ body weight equivalent to $0.25 \mathrm{~g} / 1$ liter DW \\
\hline 5 & Amoxicillin $20 \%$ & $20 \mathrm{mg} / \mathrm{kg}$ body weight equivalent to $1 \mathrm{~g} / 1$ liter DW \\
\hline 6 & Tylosin $100 \%$ & $35 \mathrm{mg} / \mathrm{kg}$ body weight equivalent to $0.5 \mathrm{~g} / 1$ liter DW \\
\hline 7 & Lincospectin & $\begin{array}{l}35 \mathrm{mg} \text { lincomycin and } 17.5 \mathrm{mg} \text { spectinomycin / } \mathrm{kg} \text { body weight } \\
\text { equivalent to } 0.5 \mathrm{~g} / 1 \text { liter DW }\end{array}$ \\
\hline 8 & Floramphenicol & $1 \mathrm{ml} / 1$ liter DW \\
\hline 9 & Enrofloxacin $10 \%$ & $10 \mathrm{mg} / \mathrm{kg}$ body weight equivalent to $1 \mathrm{ml} / 1$ liter $\mathrm{DW}$ \\
\hline 10 & Control & - \\
\hline
\end{tabular}


All antibiotics were used for 12 hrs daily, for 3 consecutive days at $14^{\text {th }}-16^{\text {th }}$ day in the first course.

Again, the antibiotic course was repeated at $29^{\text {th }}-31^{\text {st }}$ day of age then followed by acidifier $1 \mathrm{ml} / 1$ liter drinking water foe 3 successive days.

\section{Microbiological examination:}

From the killed birds after both first and second treatment courses, they were examined for

E. coli count, for total Lactobacillus sp. total Clostridium sp. and $C l$. perfringens count in the intestine.

The intestine were incised and a constant part ( $2 \mathrm{~cm}$ length) from the middle part of the intestine near the yolk sac diverticulum was cut aseptically.

The intestine pieces were opened longitudinally and cleaned out from the contents with the blunt side of a sterile scalpel without scrapping and put into specific broth media.

\section{Lactobacillus sp. count:}

From each sacrificed bird, a fixed length $(2 \mathrm{~cm})$ from the middle part of the intestine around the yolk sac diverticulum were cut aseptically, split opened using sterile scissors, cleaned out from the rough feed particle contents with the blunt side of a sterile scalpel without scrapping) and put into $5 \mathrm{cc}$ of Rogosa broth, and incubated for $2 \mathrm{hrs}$ at $37 \mathrm{C}$. Then the tubes were brought out and were ten fold serially diluted in Rogosa broth $\left(10^{2,3,4,5}\right)$. Then subculturies were made from the dilutions by taking 0.5 cc onto the corresponding Rogosa agar plates, and spread on 
it. Agar plates were kept to settle for 5 minutes. Cultured were incubated for $24 \mathrm{hr}$ in candle jar at $37 \mathrm{C}$, colonies were counted and loads per gram were calculated with the naked eye (Buratto, 1983).

\section{Clostridium sp. count:}

Also in the same way from the corresponding dilutions, a similar subculturing was made on sheep blood agar with and without neomycin sulphate for counting the Clostridium sp. colonies.

Sheep blood agar plates were incubated anaerobically at $37 \mathrm{C}$ for 48 hrs using gaspack anaerobic jar (oxoid).

\section{Gentian violet stain:}

This stain was used to differentiate the Clostridium sp. and the $C l$. perfringens.

The hemolytic colonies of $\mathrm{Cl}$. perfringens on blood agar showed non sporogenic rod shape short bacilli, while other Clostridium sp. organisms were spore forming bacilli.

\section{E. coli count:}

Test tubes containing $5 \mathrm{cc}$ nutrient broth, from which ten-fold serial dilution was done immediately and culturing was performed by taking $0.5 \mathrm{cc}$ from the assigned dilutions onto the corresponding MacConkey agar plates.

\section{Culturing media:}

- For Lactobacillus sp.:

1. Rogosa broth (Rogosa and Sharpe, 1959).

2. Rogosa agar 
- For E.coli:

1. Nutrient broth

2. MacConkey agar

3. Tetrathionate agar medium

4. Indole production test medium

5. Urea agar slant medium

6. Sugar fermentation medium: (glucose, maltose, sucrose, lactose)

7. Triple Sugar iron agar (TSI)

- For Clostridium sp.:

1. Peptone water

2. Sheep blood agar with and without neomycin-sulphate

\section{Composition of the acidifier:}

- Phosphoric acid $60 \mathrm{ml}$

- Lactic acid $20 \mathrm{ml}$

- Fumaric acid $20 \mathrm{ml}$

- Acetic acid $60 \mathrm{ml}$

- Tartaric acid $150 \mathrm{ml}$

- Propylene glycol $160 \mathrm{ml}$

- Dist. water ad. $1000 \mathrm{ml}$

Rate of addition: $1 \mathrm{ml} /$ liter of drinking water for 3 days. 


\section{RESULTS}

\section{Lactobacillus sp. Count:}

Lactobacillus sp. count after the end of antibiotic (Table, 2):

\section{4 hrs after the end of antibiotics treatment (Table, 2):}

- Spiramycin only inhibited completely the growth of Lactobacillus sp.

- Doxycycline, amoxicillin and lincospectin had moderate inhibitory effects on the Lactobacillus sp. count at this time.

- Tylosin, floramphenicol, enrofloxacin, nitroimidazole and cephradin had no inhibitory effects on the growth of Lactobacillus sp.

48 hrs after the end of antibiotics treatment (Table, 2):

- As seen in table (2) on the $2^{\text {nd }}$ day after the end of the antibiotic course, doxycycline and amoxicillin were the most severe antibiotics as they inhibited the growth of Lactobacillus sp. in dilutions above $10^{3}$.

- All other antibiotics showed no inhibitory effects on growth of Lactobacillus sp.

\section{2 hrs after the end of antibiotics (Table, 2):}

- Doxycycline was the most severe antibiotic on Lactobacillus sp. as it inhibited their growth above the $10^{3}$ dilutions.

- All other antibiotics had no inhibitory effects on Lactobacillus sp. 3 days after antibiotics treatment.

\section{1 week after the end of antibiotics (Table, 2):}

- One week after the stop of antibiotic treatment, the Lactobacillus sp. counts were similar to the control non treated group (non countable: $>150$ cfu in $10^{5}$ dilution). 
Lactobacillus sp.count after the end of antibiotic and acidifier(Table,2):

\section{4 hrs after the end of antibiotics and the acidifier (Table, 2):}

- On the first day after stop of the acidfier treatment, the growth of Lactobacillus sp. was so weak that they did not exceed dilution $10^{2}$.

- Acidifier treatment after cephradin, doxycycline, amoxicillin and lincospectin completely prevented the growth of Lactobacillus sp.

\section{8 hrs after the end of antibiotics and the acidifier (Table, 2):}

- On the second day after the acidifier treatment, there was gradual regeneration and repopulation of Lactobacillus sp. counts. Doxycycline and amoxicillin with acidifier were still inhibiting the multiplication and growth of Lactobacillus sp. which started to regenerate their population in other antibiotic groups.

- Acidifier treatment after cephradin and lincospectin had noticeable inhibitory effects on Lactobacillus sp. as they allowed the growth of Lactobacillus sp. in dilutions not above $10^{2}$.

- Acidifier treatment after the remaining antibiotics (spiramycin, nitroimidazole and floramphenicol) had moderate inhibitory effect on the growth of Lactobacillus sp.

- Acid treatment after tylosin and enrofloxacin had no inhibitory effects on Lactobacillus sp. growth 2 days after the end of the treatment.

\section{2 hrs after the end of antibiotics and acidifier (Table, 2):}

- On the third day after the end of treatment, acidifier after doxycycline was still able to prevent completely Lactobacillus sp. growth in all dilutions. 
- Acidifier after cephradin, spiramycin, amoxicillin and lincospectin had moderate inhibitory effects on Lactobacillus sp. growth on the third day after end of treatment.

- Acidifier after nitroimidazole, tylosin, floramphenicol and enrofloxacin had no inhibitory effects at all at this time (3 days after treatment). There was gradual regeneration of Lactobacillus sp. count which nearly returned to the normal load as in the control group.

\section{1 week after the end of antibiotics and acidifier (Table, 2):}

- Aacidifier after spiramycin and doxycycline treatment had the most inhibitory effect on Lactobacillus sp. count.

- It is worth to notice that antibiotics and acidifier resulted in Lactobacillus sp. counts that were one log lower $\left(10^{4}\right)$ than that of the count in case of antibiotics without acidifier $\left(10^{5}\right)$ one week after end of the treatment.

E. coli counts:

\section{E. coli counts after the end of antibiotics treatment (Table, 3):}

\section{4 hrs after the end of antibiotics treatment:}

- There was no growth obtained with cephradin, spiramycin, doxycycline, tylosin and floramphenicol. Other antibiotics allowed moderate growth rate in a maximum concentration of $10^{3}$.

\section{$48 \mathrm{hrs}$ after the end of antibiotics treatment (Table, 3 ):}

- E. coli grew with all antibiotic groups, in concentrations generally higher than those after 24 hrs. The most effective antibiotics were cephradin and tylosin. The least effective were amoxicillin and lincospectin. 
72 hrs after the end of antibiotics (Table, 3):

- The most effective antibiotics were nitroimidazole, tylosin, floramphenicol and enrofloxacin.

The least effective drugs, at this time, were cephradin, spiramycin, doxycycline, amoxicillin and lincospectin.

1 week after the end of antibiotics (Table, 3 ):

- One week after the stop of all antibiotics treatment,E.coli counts returned to the same concentrations as the control.

$E$. coli counts after the end of antibiotic and acidifier (Table, 3):

$24 \mathrm{hrs}$ after the end of antibiotics and the acidifier (Table, 3):

- No growth was seen in any group.

48 hrs after the end of antibiotics and the acidifier (Table, 3):

- Acidifier treatment after spiramycin, doxycycline, amoxicillin, tylosin, lincospectin, and floramphenicol inhibited completely the growth of E. coli.

- While, acidifier treatment after cephradin, enrofloxacin and nitroimidazole had moderate inhibitory effects.

72 hrs after the end of antibiotics and acidifier (Table, 3):

- Non of the antibiotics and the acidifier had prevented E. coli from the growth. 
1 week after the end of antibiotics and acidifier (Table, 3):

- One week after the stop of acidifier treatment, the E. coli counts were one $\log \left(10^{4}\right)$ less than if no acidifier was used (NC: non countable in $10^{5}$ dilution).

\section{Clostridium sp. Counts:}

Clostridium sp. counts after the end of antibiotic (Table, 4):

\section{4 hrs after end of antibiotics treatment (Table, 4):}

- There was no isolation of $\mathrm{Cl}$. perfringens with cephradin, spiramycin, nitroimidazole, doxycycline, amoxicillin and lincospectin. But cephradin, spiramycin, lincospectin, floramphenicol, enrofloxacin inhibited other Clostridium sp. It could be concluded that cephradin, spiramycin and lincospectin prevented both $\mathrm{Cl}$. perfringens and other Clostridium sp.

\section{8 hrs after end of antibiotics treatment (Table, 4):}

- Cephradin, spiramycin, doxycycline, amoxicillin, tylosin, lincospectin and enrofloxacin inhibited

- $C l$. perfringens, while cephradin, spiramycin, doxycycline, tylosin, lincospectin and enrofloxacin

- had prevented the growth of other Clostridium sp.

\section{2 hrs after the end of antibiotics (Table, 4):}

- Spiramycin, doxycycline, tylosin, lincospectin and enrofloxacin inhibited the growth of $\mathrm{Cl}$. perfringens, while other antibiotics did not affect the growth of this organism. Antibiotics did not prevented the growth of other Clostridium sp. at this time of testing. 
1 week after the end of antibiotics (Table, 4):

- Results were similar to that of $72 \mathrm{hrs}$. Spiramycin, doxycycline, tylosin, lincospectin and enrofloxacin inhibited the growth of $\mathrm{Cl}$. perfringens.

- Other Clostridium sp. were not inhibited by any antibiotic.

Clostridium sp. counts after the end of antibiotic and acidifier(Table, 5): 24 hrs after the end of antibiotics and the acidifier (Table, 5):

- All antibiotics followed by acidifier, prevented the growth of $\mathrm{Cl}$. perfringens. But acidifier after nitroimidazole, doxycycline and amoxicillin prevented the growth of other Clostridium sp.

48 hrs after the end of antibiotics and the acidifier (Table, 5):

- Also, all antibiotics followed by acidifier, inhibited completely the growth of $\mathrm{Cl}$. perfringens. While acidifier after amoxicillin, lincospectin and enrofloxacin had prevented the growth of other Clostridium sp.

72 hrs after the end of antibiotics and acidifier (Table, 5):

- Acidifier and antibiotics in all the groups inhibited the growth and multiplication of $\mathrm{Cl}$. perfringens. While acidifier after amoxicillin, lincospectin and enrofloxacin prevented the growth of other Clostridium sp.

1 week after the end of antibiotics and acidifier (Table, 5):

- Acidifier and antibiotics in all the groups inhibited the growth and multiplication of $\mathrm{Cl}$. perfringens. Meanwhile, other Clostridium sp. showed high rate of multiplication in all antibiotic groups. 
Ellakany, H.F. et al.,

Table (2): Intestinal Lactobacillus sp. counts after antibiotic or antibiotic and acidifier treatment.

\begin{tabular}{||c||c|c|c|c||c|c|c|c||}
\hline \multirow{2}{*}{ Treatment } & \multicolumn{4}{|c||}{ Count after antibiotics alone } & \multicolumn{3}{c||}{ Count after antibiotics and acidifier } \\
\cline { 2 - 10 } & $\mathbf{2 4} \mathbf{~ h r s}$ & $\mathbf{4 8} \mathbf{~ h r s}$ & $\mathbf{7 2} \mathbf{~ h r s}$ & $\mathbf{7}$ days & $\mathbf{2 4} \mathbf{~ h r s}$ & $\mathbf{4 8} \mathbf{~ h r s}$ & $\mathbf{7 2} \mathbf{~ h r s}$ & $\mathbf{7}$ days \\
\hline \hline Cephradin & $78 \times 10^{4}$ & $53 \times 10^{4}$ & $2 \times 10^{4}$ & $\mathrm{NC}$ & - & $45 \times 10^{2}$ & $5 \times 10^{3}$ & $50 \times 10^{4}$ \\
\hline Spiramycin & - & $38 \times 10^{4}$ & $62 \times 10^{5}$ & $\mathrm{NC}$ & $3 \times 10^{2}$ & $4 \times 10^{3}$ & $12 \times 10^{3}$ & $42 \times 10^{3}$ \\
\hline Nitroimidazole & $116 \times 10^{4}$ & $78 \times 10^{4}$ & $18 \times 10^{5}$ & $\mathrm{NC}$ & $50 \times 10^{2}$ & $25 \times 10^{3}$ & $33 \times 10^{4}$ & $150 \times 10^{4}$ \\
\hline Doxycycline & $8 \times 10^{3}$ & $30 \times 10^{3}$ & $8 \times 10^{3}$ & $\mathrm{NC}$ & - & - & - & $17 \times 10^{3}$ \\
\hline Amoxicillin & $2 \times 10^{2}$ & $63 \times 10^{3}$ & $2 \times 10^{5}$ & $\mathrm{NC}$ & - & - & $33 \times 10^{3}$ & $10 \times 10^{4}$ \\
\hline Tylosin & $10 \times 10^{4}$ & $116 \times 10^{4}$ & $6 \times 10^{5}$ & $\mathrm{NC}$ & $25 \times 10^{2}$ & $17 \times 10^{4}$ & $14 \times 10^{4}$ & $42 \times 10^{4}$ \\
\hline Lincospectin & $2 \times 10^{3}$ & $15 \times 10^{4}$ & $\mathrm{NC}$ & $\mathrm{NC}$ & - & $3 \times 10^{2}$ & $7 \times 10^{3}$ & $30 \times 10^{4}$ \\
\hline Floramphenicol & $7 \times 10^{4}$ & $22 \times 10^{4}$ & $65 \times 10^{4}$ & $\mathrm{NC}$ & $8 \times 10^{2}$ & $10 \times 10^{3}$ & $10 \times 10^{4}$ & $24 \times 10^{4}$ \\
\hline enrofloxacin & $22 \times 10^{4}$ & $38 \times 10^{4}$ & $\mathrm{NC}$ & $\mathrm{NC}$ & $27 \times 10^{2}$ & $7 \times 10^{4}$ & $46 \times 10^{4}$ & $35 \times 10^{4}$ \\
\hline Control & $\mathrm{NC}$ & $\mathrm{NC}$ & $\mathrm{NC}$ & $\mathrm{NC}$ & $\mathrm{NC}$ & $\mathrm{NC}$ & $\mathrm{NC}$ & $\mathrm{NC}$ \\
\hline \hline
\end{tabular}

$\mathrm{NC}=$ Non countable $>150 \mathrm{cfu} \times 10^{5}$

$-=$ negative

Table (3): Intestinal E. coli counts after antibiotic or antibiotic and acidifier treatment.

\begin{tabular}{|l||c|c|c|c||c|c|c|c||}
\hline \multirow{2}{*}{ Treatment } & \multicolumn{5}{c||}{ Count after antibiotics alone } & \multicolumn{3}{c||}{ Count after antibiotics and acidifier } \\
\cline { 2 - 10 } & $\mathbf{2 4} \mathbf{~ h r s}$ & $\mathbf{4 8} \mathbf{~ h r s}$ & $\mathbf{7 2} \mathbf{~ h r s}$ & $\mathbf{7}$ days & $\mathbf{2 4} \mathbf{~ h r s}$ & $\mathbf{4 8} \mathbf{~ h r s}$ & $\mathbf{7 2} \mathbf{~ h r s}$ & $\mathbf{7}$ days \\
\hline Cephradin & - & $15 \times 10^{2}$ & $80 \times 10^{4}$ & $\mathrm{NC}$ & - & $17 \times 10^{3}$ & $30 \times 10^{4}$ & $85 \times 10^{4}$ \\
\hline Spiramycin & - & $7 \times 10^{3}$ & $7 \times 10^{4}$ & $\mathrm{NC}$ & - & - & $80 \times 10^{4}$ & $100 \times 10^{4}$ \\
\hline Nitroimidazole & $4 \times 10^{3}$ & $8 \times 10^{3}$ & $65 \times 10^{3}$ & $\mathrm{NC}$ & - & $73 \times 10^{3}$ & $61 \times 10^{4}$ & $80 \times 10^{4}$ \\
\hline Doxycycline & - & $7 \times 10^{3}$ & $2 \times 10^{4}$ & $\mathrm{NC}$ & - & - & $7 \times 10^{3}$ & $65 \times 10^{4}$ \\
\hline Amoxicillin & $65 \times 10^{3}$ & $4 \times 10^{4}$ & $14 \times 10^{4}$ & $\mathrm{NC}$ & - & - & $25 \times 10^{3}$ & $13 \times 10^{4}$ \\
\hline Tylosin & - & $35 \times 10^{2}$ & $5 \times 10^{3}$ & $\mathrm{NC}$ & - & - & $4 \times 10^{4}$ & $33 \times 10^{4}$ \\
\hline Lincospectin & $100 \times 10^{3}$ & $28 \times 10^{4}$ & $42 \times 10^{4}$ & $\mathrm{NC}$ & - & - & $42 \times 10^{4}$ & $113 \times 10^{4}$ \\
\hline Floramphenicol & - & $17 \times 10^{3}$ & $67 \times 10^{3}$ & $\mathrm{NC}$ & - & - & $30 \times 10^{4}$ & $110 \times 10^{4}$ \\
\hline enrofloxacin & $\mathrm{NCx} 10^{3}$ & $67 \times 10^{3}$ & $50 \times 10^{3}$ & $\mathrm{NC}$ & - & $2 \times 10^{3}$ & $42 \times 10^{3}$ & $130 \times 10^{4}$ \\
\hline Control & $\mathrm{NC}$ & $\mathrm{NC}$ & $\mathrm{NC}$ & $\mathrm{NC}$ & $\mathrm{NC}$ & $\mathrm{NC}$ & $\mathrm{NC}$ & $\mathrm{NC}$ \\
\hline
\end{tabular}

$\mathrm{NC}=$ Non countable $>150 \mathrm{cfu} \times 10^{5}$

- = negative

$\overline{\text { Kafrelsheikh Vet. Med. J. Vol. } 7 \text { No. } 1 \text { (2009) }}$ 
The Effect Of Antibiotics And Acidifier Treatment...

Table (4): Intestinal Clostridium sp. counts after antibiotic treatment.

\begin{tabular}{|c|c|c|c|c|c|c|c|c|}
\hline \multirow[b]{2}{*}{ Treatment } & \multicolumn{2}{|c|}{$24 \mathrm{hrs}$} & \multicolumn{2}{|c|}{$48 \mathrm{hrs}$} & \multicolumn{2}{|c|}{$72 \mathrm{hrs}$} & \multicolumn{2}{|c|}{7 days } \\
\hline & $\begin{array}{c}\text { Cl. } \\
\text { perfri- } \\
\text { ngens }\end{array}$ & $\begin{array}{c}\text { Other } \\
\text { Clostrid- } \\
\text { ium sp. }\end{array}$ & $\begin{array}{c}\text { Cl. } \\
\text { perfri- } \\
\text { ngens }\end{array}$ & $\begin{array}{c}\text { Other } \\
\text { Clostrid- } \\
\text { ium sp. }\end{array}$ & $\begin{array}{c}\text { Cl. } \\
\text { perfri- } \\
\text { ngens }\end{array}$ & $\begin{array}{c}\text { Other } \\
\text { Clostrid- } \\
\text { ium sp. }\end{array}$ & $\begin{array}{c}\text { Cl. } \\
\text { perfri- } \\
\text { ngens }\end{array}$ & $\begin{array}{c}\text { Other } \\
\text { Clostrid- } \\
\text { ium sp. }\end{array}$ \\
\hline Cephradin & - & - & - & - & $13 \times 10^{3}$ & $35 \times 10^{3}$ & $24 \times 10^{3}$ & $\mathrm{NC}$ \\
\hline Spiramycin & - & - & - & - & - & $8 \times 10^{2}$ & - & $\mathrm{NC}$ \\
\hline Nitroimidazole & - & $15 \times 10^{3}$ & $20 \times 10^{2}$ & $25 \times 10^{3}$ & $17 \times 10^{3}$ & $35 \times 10^{2}$ & $19 \times 10^{3}$ & $\mathrm{NC}$ \\
\hline Doxycycline & - & $17 \times 10^{3}$ & - & - & - & $10 \times 10^{3}$ & - & $\mathrm{NC}$ \\
\hline Amoxicillin & - & $8 \times 10^{2}$ & - & $18 \times 10^{3}$ & $3 \times 10^{3}$ & $2 \times 10^{3}$ & $8 \times 10^{3}$ & $\mathrm{NC}$ \\
\hline Tylosin & $4 \times 10^{3}$ & $14 \times 10^{3}$ & - & - & - & $25 \times 10^{2}$ & - & $\mathrm{NC}$ \\
\hline Lincospectin & - & - & - & - & - & $35 \times 10^{3}$ & - & $\mathrm{NC}$ \\
\hline Floramphenicol & $2 \times 10^{3}$ & - & $2 \times 10^{4}$ & $27 \times 10^{3}$ & $7 \times 10^{3}$ & $15 \times 10^{3}$ & $9 \times 10^{3}$ & $\mathrm{NC}$ \\
\hline enrofloxacin & $2 \times 10^{2}$ & - & - & - & - & $10 \times 10^{3}$ & - & $\mathrm{NC}$ \\
\hline Control & $4 \times 10^{4}$ & $2 \times 10^{4}$ & $7 \times 10^{3}$ & $\mathrm{NC}$ & $8 \times 10^{3}$ & $13 \times 10^{4}$ & $11 \times 10^{3}$ & $\mathrm{NC}$ \\
\hline
\end{tabular}

$\mathrm{NC}=$ Non countable $>150 \mathrm{cfu} \times 10^{5}$

- = negative

Table (5): Intestinal Clostridium sp.counts after antibiotic and acidifier treatment.

\begin{tabular}{|c|c|c|c|c|c|c|c|c|}
\hline \multirow[b]{2}{*}{ Treatment } & \multicolumn{2}{|c|}{$24 \mathrm{hrs}$} & \multicolumn{2}{|c|}{$48 \mathrm{hrs}$} & \multicolumn{2}{|c|}{$72 \mathrm{hrs}$} & \multicolumn{2}{|c|}{7 days } \\
\hline & $\begin{array}{c}\text { Cl. } \\
\text { perfri- } \\
\text { ngens }\end{array}$ & $\begin{array}{c}\text { Other } \\
\text { Clostrid- } \\
\text { ium sp. }\end{array}$ & $\begin{array}{c}\text { Cl. } \\
\text { perfri- } \\
\text { ngens }\end{array}$ & $\begin{array}{c}\text { Other } \\
\text { Clostrid- } \\
\text { ium sp. }\end{array}$ & $\begin{array}{c}\text { Cl. } \\
\text { perfri- } \\
\text { ngens }\end{array}$ & $\begin{array}{c}\text { Other } \\
\text { Clostrid- } \\
\text { ium sp. }\end{array}$ & $\begin{array}{c}\text { Cl. } \\
\text { perfri- } \\
\text { ngens }\end{array}$ & $\begin{array}{c}\text { Other } \\
\text { Clostrid- } \\
\text { ium sp. }\end{array}$ \\
\hline Cephradin & - & $15 \times 10^{2}$ & - & $7 \times 10^{3}$ & - & $5 \times 10^{3}$ & - & $\mathrm{NC}$ \\
\hline Spiramycin & - & $3 \times 10^{3}$ & - & $2 \times 10^{3}$ & - & $14 \times 10^{3}$ & - & $\mathrm{NC}$ \\
\hline Nitroimidazole & - & - & - & $20 \times 10^{3}$ & - & $24 \times 10^{3}$ & - & $\mathrm{NC}$ \\
\hline Doxycycline & - & - & - & $20 \times 10^{2}$ & - & $18 \times 10^{2}$ & - & $\mathrm{NC}$ \\
\hline Amoxicillin & - & - & - & - & - & - & - & $\mathrm{NC}$ \\
\hline Tylosin & - & $5 \times 10^{3}$ & - & $46 \times 10^{2}$ & - & $21 \times 10^{2}$ & - & $\mathrm{NC}$ \\
\hline Lincospectin & - & $25 \times 10^{3}$ & - & - & - & - & - & $\mathrm{NC}$ \\
\hline Floramphenicol & - & $2 \times 10^{2}$ & - & $25 \times 10^{2}$ & - & $17 \times 10^{2}$ & - & $\mathrm{NC}$ \\
\hline enrofloxacin & - & $3 \times 10^{2}$ & - & - & - & - & - & $\mathrm{NC}$ \\
\hline Control & $3 \times 10^{3}$ & $16 \times 10^{4}$ & $6 \times 10^{3}$ & $18 \times 10^{4}$ & $3 \times 10^{3}$ & $15 \times 10^{4}$ & $2 \times 10^{3}$ & $\mathrm{NC}$ \\
\hline
\end{tabular}

$\mathrm{NC}=$ Non countable $>150 \mathrm{cfu} \times 10^{5}$

- = negative

Kafrelsheikh Vet. Med. J. Vol. 7 No. 1 (2009) 


\section{DISCUSSION}

The aim of the present study was to highlight the detailed effects of some commonly used antibiotics in the local poultry field practice on the counts of main 3 important microbes: Lactobacillus sp., E. coli and Clostridium sp.

Cephradin is one of the cephalosporins, which is a member of Betalactam antibiotics. Cephalosporins cover a broad range of organisms including both Gram +ve and Gram -ve (E. coli).

Bridges et al.(1952,1953)indicated that penicillin (Beta-lactam) and occasionally streptomycin increased fecal shedding of Coliforms. Mamber and Kaltz (1985) found that birds fed a diet containing penicillin (20 mg/kg feed) appeared to cause proliferation of Klebsiella pneumoniae and increased Salmonella in the crop, gizzard, and cecal contents. In the same way, Hinton et al. (1986) indicated that the use of penicillin in broilers feed at $20 \mathrm{mg} / \mathrm{kg}$ increased Salmonella shedding.

In an in-vitro study, Rayhan (2007) found that rifampicin, ampicillin, amoxicillin and ceftiofur were the most effective antibiotics against $\mathrm{Cl}$. perfringens $\mathrm{A}, \mathrm{B}, \mathrm{C}$ and $\mathrm{C}$.

Our results showed that cephradin had no inhibitory activity against Lactobacillus sp. but it had slight inhibitory effects on E. coli and had a good inhibitory effect against both $\mathrm{Cl}$. perfringens and other Clostridium sp.

Spiramycin is a macrolide that acts mainly on Mycoplasma sp. and is used extensively in the poultry therapeutics.

In this trial, spiramycin, showed good inhibitory effects against both $\mathrm{Cl}$. perfringens and other Clostridium sp.

Nitroimidazole had been licensed very lately in the Egyptian market for the treatment of necrotic enteritis. This study showed that this drug did not produce inhibitory effects against $C l$. perfringens and other Clostridium $\mathrm{sp}$. 
Doxycycline is a semi-synthetic tetracycline invented and clinically developed in the early 1960s and is used as one of best drugs for treatment of the CCRD problem in chickens.

Amoxicillin is a moderate-spectrum, bacteriolytic, $\beta$-lactam antibiotic used to treat bacterial infections caused by susceptible microorganisms. Amoxicillin is used extensively to treat necrotic enteritis caused by $\mathrm{Cl}$. perfringens.

Doxycycline and amoxicillin had the most inhibitory effect on Lactobacillus sp. This inhibitory effect was more pronounced when an acidifier was used after them than if the antibiotics were used alone.

Also, doxycycline and amoxicillin exhibited an inhibitory action on Cl. perfringens and other Clostridium sp.

Tylosin is a macrolide-class antibiotic with a good activity against Mycoplasma sp., Gram positive organisms including Clostridium sp. and a limited range of gram negative organisms. Tylosin is used in the Egyptian poultry market for over 30 years.

Ellakany et al. (2008) found that tylosin did not have a drastic effect on Lactobacillus sp. count in the duodenum of broilers.

The findings of this showed that tylosin had an inhibitory effects on both $C l$. perfringens and Clostridium sp. as well as on E. coli.

Lincospectin is a combination of licomycin and spectinomycin. Lincomycin antibiotic belongs to the lincosamide group that is very close to the macrolides and acts on Mycoplasma sp. and Clostridium sp. While spectinomycin is aminoglycoside that acts mainly on Gram -ve bacteria (E. coli). This combination of antibiotics is used in the local poultry industry in large scale either in drinking water or as parentrally for the control of the CCRD problem. Lincospectin in this study had moderate inhibitory effects on Lactobacillus sp. and E. coli, but showed better inhibitory action on $\mathrm{Cl}$. perfringens and other Clostridium sp. 
Enrofloxacin is a fluoroquinolone antibiotic acts by inhibition of DNA gyrase responsible for hypercoiling of DNA in the nucleus of an organism. This study showed good inhibitory effects of enrofloxacin on both E. coli, Cl. perfringens and other Clostridium sp.

Organic acids are group of feed additives that are needed to suppress the growth and multiplication of Salmonella and E. coli in the digestive tract of birds through decreasing the $\mathrm{pH}$.

Organic acids in their undissociated forms are able to pass through the cell membrane of bacteria. Once inside the cell, the acid dissociates to produce $\mathrm{H}+$ ions which lower the $\mathrm{pH}$ of the cell causing the organism to use its energy trying to restore the normal balance, whereas the RCOO- anions produced from the acid can disrupt DNA and protein synthesis, putting the organism under stress and becomes unable to replicate. Organic acids are used to inhibit pathogens like Salmonella and E. coli in both raw materials and finished feed (Radcliffe, 2000).

Ellakany et al. (2004) mentioned that acidifier decreased the fecal shedding of the challenge strain of Salmonella enteritidis for $96 \mathrm{hrs}$ postinfection (PI).

One week after end of the antibiotics and acidifier treatment led to decrease in both Lactobacillus sp., E. coli and Clostridium sp counts with one log lower $\left(10^{4}\right)$ than that count in case of antibiotics without acidifier $\left(10^{5}\right)$.

This study results showed that acidifier after antibiotics treatment had mild inhibitory effects on Lactobacillus sp. counts, but it had a favorable inhibitory effects on $\mathrm{E}$. coli and $\mathrm{Cl}$. perfringens and other Clostridium sp. population counts in the intestine. Hence, we recommend the usage of acidifiers after each course of antibiotics to control the harmful microbial proliferation in the intestinal tract of chickens. 
Spiramycin, cephradin, amoxicillin, doxycycline, tylosin, lincospectin and enrofloxacin were effective against $\mathrm{Cl}$. perfringens. The antibacterial action of these antibiotics on Clostridium sp. was increased by addition of an acidifier afterwards.

Cephradin, spiramycin, doxycycline, tylosin, floramphenicol and enrofloxacin showed a good inhibitory effects on E. coli. This result concerning E. coli can not be taken as a model because of the continuous change in the drug sensitivity of this bacterium.

\section{CONCLUSION}

Amoxicillin and doxycycline showed strong growth inhibitory effect against Lactobacillus sp. and Cl.perfringens either alone or with an acidifier.

Cephradin, nitroimidazole, tylosin, lincospectin, floramphenicol and enrofloxacin had no effect on Lactobacillus sp. counts in the intestine.

Although some antibiotics showed high efficacy against E. coli, but this can not be seen as a recommendation model as the sensitivity of this organism is changeable in short periods because of rapidly acquiring resistance.

Spiramycin, cephradin, amoxicillin, doxycycline, tylosin, lincospectin and enrofloxacin were effective against $\mathrm{Cl}$. perfringens and other Clostridium sp.

Acidifier showed a great inhibitory activity against $E$. coli. So, it could be recommended that acidifiers help to decrease the load of E. coli in the chicken intestine which may have a good contribution to the protection against colisepticemia and CCRD problem. This is also important to subsequently decrease their shedding in the feces and to decrease the environment contamination. 


\section{REFERENCES}

- Bridges, J.H.; I.A. Dyer; and J.J. Powers (1953). Penicillin and streptomycin affect the microflora of the intestinal tract of pigs. (1953). J. Anim. Sci. 12:96-101.

- Bridges, J.H.; I.A. Dyer; and W.C. Burkhart (1952). Effects of penicillin and streptomycin on the growth rate and bacterial count in the faeces of the pig. (1952). J. Anim. Sci. 11:474.479.

- Buratto, L. (1983). The natural yeast as a growth factor. Proceedings of the meeting called by Doxal, Italia, S.P.A. Verone Agriculture Fair, 19-21.

- Cant, J. P.; B. W. McBride and W. J. Croom, Jr. (1996). The regulation of intestinal metabolism and its impact on whole animal energetics. J. Anim. Sci. 74:2541-2553.

- Cruickshank, R.; J.P. Duguid; B.P. Marmion and R.H.A. Swain (1975). Medical Microbiology. $12^{\text {th }}$ Ed., Vol. II. Page 417. Churchill. Livingstone, London.

- Ellakamy, H.F.; A. M. Awad, and S. H. Abd EL-Hamid (2008). A contribution to the usage of tylosin tartrate during brooding broiler chicks for the control of vertically transmilted my coplasma gallispepticum. The 8th Scientific conference of the Egyptian Vet. Poultry Assocciatio, March 10-13, 2008.

- Ellakany, H.F.; M.S.H. Rezk; A.M. Awad and H.S. Abd El-Hamid. (2004). The role of probiotic and acidifier in the protection against experimental infection of Salmonella enteritidis in broiler chickens. The First International Conference of the Veterinary Research Division of The National Research Center, Cairo, 15-17 February, p.181-194. 
- Feighner, S. D., and M. P. Dashkevicz (1987). Subtherapeutic levels of antibiotics in poultry feeds and their effects on weight gain, feed efficiency, and bacterial cholytaurine hydrolase activity. Appl. Environ. Microbiol. 53:331-336.

- Feighner, S. D., and M. P. Dashkevicz (1988). Effect of dietary carbohydrates on bacterial cholytaurine hydrolase in poultry intestinal homogenates. Appl. Environ. Microbiol. 54:337-342.

- Furuse, M., and H. Yokota (1985). Effect of the gut microflora on chick growth and utilization of protein and energy at different concentrations of dietary protein. Br. Poult. Sci. 26:97-104.

- Furuse, M., and J. Okumura (1994). Nutritional and physiological characteristics in germ-free chickens. Comp. Biochem. Physiol. 109A: 547-556.

- Gaskins, H. R. (2001). Intestinal bacteria and their influence on swine growth. Pages 585-608 in Swine Nutrition. 2nd ed. A. J. Lewis and L. L. Southern, ed. CRC Press, Boca Raton, FL.

- Gaskins, H. R.; C. T. Collier, and D. B. Anderson (2002). Antibiotics as growth promotants: Mode of action. Anim. Biotechnol., 13: 39-42.

- Hinton M.;Z.A.M.Al-Chalaby;and A.H.Linton(1986). The influence of dietary protein and antimicrobial feed additives on Salmonella carriage by broiler chickens. Veterinary Record. 119: 495-500.

- Jensen, B. B. (2001). Possible ways of modifying type and amount of products from microbial fermentation in the gut. Pages: 181-200 in Gut Environment of Pigs. A. Piva, K. E. Bach, 642. Dibner and Richards. 
- Lee, A. (1984). Neglected niches: The microbial ecology of the gastrointestinal tract. Pages 115-162 in Advances in Microbal Ecology. K. Marshall, ed. Plenum Press, New York.

- Moore, P. R., A. Evenson, T. D. Luckey, E. McCoy, E. A. Elvehjem, and E. B. Hart. (1946). Use of sulphasuccidine, streptothricin and streptomycin in nutrition studies with the chick. J. Biol. Chem. 165:437-441.

- Mackie, R. I., A. Sghir, and H. R. Gaskins (1999). Developmental microbial ecology of the neonatal gastrointestinal tract. Am. J. Clin. Nutr. 69:1035S

- Mamber, S. and S.E. Kaltz (1985). Effects of antimicrobial agents fed to chickens on some gram-negative enteric bacilli. Appl Environ Microbiol. 50:638-48.

- Moore, W. E. and L. V. Holdeman (1974). Human faecal flora: The normal flora of 20 Japanese-Hawaiians. Appl. Micriobiol, 27: 961979.

- Moore, W. E. C., L. V. H. Moore, E. P. Cato, T. D. Wilkins and E. T. Kornegay (1987). Effect of high-fiber and high-oil diets on the fecal flora of swine. Appl. Environ. Microbiol, 53: 1638-44..

- Radcliffe, J. (2000). British supermakets: forgoing changes in poultry nutritition. Australian Poultry Symposium, 12: 25-31.

- Rayhan, E.A. (2007). Studies on necrotic enteritis in chickens. Ph.D. thesis, Poultry Diseases, Cairo University.

- Rogasa,M.A.and M.E.Sharpe (1959). The approach to the classification of lactobacilli. J. Appl. Bact., 2: 329-340. 
- Savage, D. C. (1977). Microbial ecology of the gastrointestinal tract. Annu. Rev. Microbiol. 31:107-133.

- Smith,H.W., and J.E. T. Jones (1963). Observation on the alimentary tract and its bacterial flora in healthy and diseased pigs. J. Pathol. Bacteriol. 86:387.

- Snel, J., H. J. M. Harmssen, P. W. J. J. van der Wielen, and B. A. Williams (2002). Dietary strategies to influence the gastrointestinal microflora of young animals, and its potential to improve intestinal health. Pages 37-69 in Nutrition and Health of the Gastrointestinal Tract. M. C. Blok, H. A. Vahl, L. de Lange, A. E. van de Braak, G. Hemke, and M. Hessing, ed. Wageningen Academic Publishers, Wageningen, The Netherlands.

- Summers, M. (1991). Energy metabolism in the broiler chick. Ph.D. Thesis. University of Guelph, Ontario, Canada.

- Vervaeke, I. J.; J. A. Decuypere; N. A. Dierick and H. K. Henderickx (1979). Quantitative in vitro evaluation of the energy metabolism influenced by virginiamycin and spiramycin used as growth promoters in pig nutrition. J. Anim. Sci. 79:846-856.

- Visek, W. J. (1978). The mode of growth promotion by antibiotics. J. Anim. Sci. 46:1447-1469. Hinton M. Salmonella colonization in young chickens given feed supplemented with the growth promoting antibiotic avilamycin. (1988). J. Vet Pharmacol Ther. 11(3):269-275. 


\section{تأثير بعض المضادات الحيوية والمحمضات على العدد الميكروبي لبكتيريا الللاكتوباسيللس النافعة

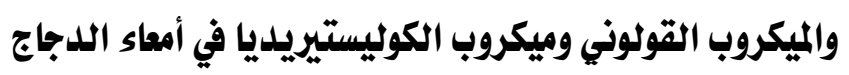

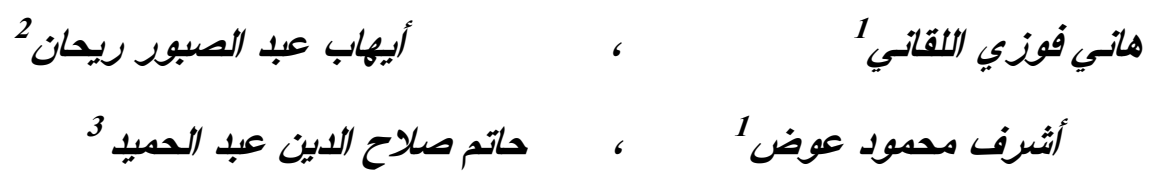

1 قسم أمر اض الدواجن و الأسماك ، كلية الطب البيطري ، جامعة الإسكندرية 2 معهز بحوث صحة الحيوان ، فرع دمنهور 3 كلية الطب البيطري ، جامعة الإسكندرية ، فرع دمنهور

ثم في هذه الدراسة عمل تجربة لبحث تأثير بعض المضادات الحيوية الثنائعة الاستعمال في حقل الدواجن على العدد الميكروبي لبعض أنواع البكتيريا الهامة في أمعاء الدجاج وهي : بكتيريا اللاكتوباسيللس النافعة، الميكروب القولوني،وميكروب الكوليستيريديا وخصوصا سلالة الكوليستيريديا

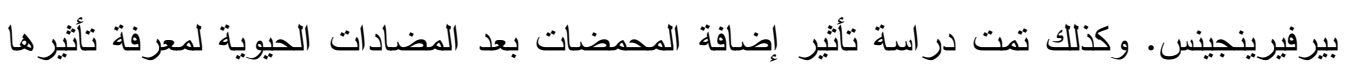
المكمل أو المغاير لنأثير هذه المضادات الحيوية.

وقد أظهرت النتائج أن السبير اميسين، السيفرادين، الأموكسيسيللين، الدوكسيسيللين، التيلوزين، اللينكوسبكتين، الأنروفلوكساسين كان لهم تأثير جيد لمنع تكاثز الكولستريديا. كما أظهرت النتائج أيضا أن الأموكسيسيللين، الدوكسيسيللين لهما تأثير غير محبب على تكاثر البكتيريا النافعة من اللاكتو باسيللس.

أيضا تم أستخلاص أن السبير اميسين، السيفر ادين، الدوكسيسيللين، التيلوزين، الأنروفلوكساسين

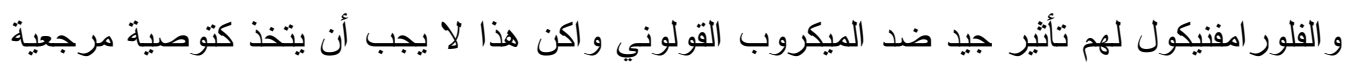
لأن هذا الميكروب يغير من حساسيته للمضادات الحيوية باستمر ار . وقد زادت قدرة المضادات الحيوية على هنع تكاثر الميكروبات الثلاثة عند أتباع هذه

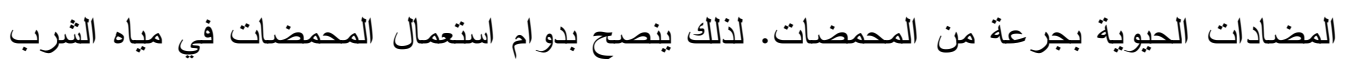
للاجاج لزيادة فعالية المضادات الحيوية. 